\title{
PENERAPAN PRINSIP-PRINSIP MUTU DAN KEAMANAN PANGAN TEMPE DI KABUPATEN LAMPUNG BARAT
}

\author{
(Application of Food Quality and Safety Principles in Tempeh Production in West Lampung)
}

\author{
Suhartono ${ }^{1}$, Ahmad Sulaeman², dan Budi Setiawan ${ }^{2}$
}

${ }^{1}$ Program Studi Manaj emen Ketahahan Pangan (MKP), Sekolah Pascasarjana, IPB.

2 Departemen Gizi Masyarakat, Fakultas Ekologi Manusia (FEMA), IPB

Tel: 0251-8628304/ 8621258; Fax: 0251-8625846/ 8622276.

\begin{abstract}
Food Law No. 71996 defined food security as a condition in which the fulfillment of food for the household is reflected by the availability of sufficient food both its quantity and quality, safe, evenly distributed and within reach; meanwhile, food quality is defined as the value determined base on the criteria of food safety, nutrition content and trade standard on food stuffs, catables and beverages. The purpose of this study was to analyze the application of food quality and safety principles in the production of food product i.e tempeh at small scale industry in West Lampung. A survey on 15 selected tempeh producers was carried out using a structured questionnaire. Primary and secondary data was collected in this study through interview and observation to the 15 tempeh producers. In the general, all producers had not fully implemented food safety and quality principles as outlined in the GMP guideline. Nevertheless, the tempeh quality produced in West Lampung organoleptically was good. Several issues need to be improved i.e. cleaning raw material (soy bean), using water from safe sources, washing soy bean before and after braising, controlling small animal included mouse, and maintenance and cleany the premises.
\end{abstract}

Keywords: food security, tempeh, hygiene, food safety, sanitation.

\section{PENDAHULUAN}

Pangan merupakan hal yang sangat penting untuk diperhatikan dalam kehidupan karena merupakan hak azasi manusia. Pembangunan ketahanan pangan pada dasarnya dimaksudkan untuk meningkatkan kualitas sumber daya manusia melalui aspek ketersediaan, distribusi dan konsumsi. Penyediaan, distribusi dan konsumsi pangan tidak hanya cukup dilihat dari jumlah yang dibutuhkan tetapi yang lebih penting adalah bagaimana pangan tersebut aman dan bermutu untuk memenuhi kebutuhan manusia.

Penelitian tentang tempe sepanjang pengetahuan peneliti selama ini baru memfokuskan pada aspek sosio-ekonomi dan aspek karakteristik tempe (sifat kimia, fisik, mikro biologi dan kandungan gizi). Keadaan ini yang mendorong peneliti untuk mengadakan penelitian dari aspek penerapan sistem yang dibangun/ dilakukan pengrajin dalam memproduksi tempe, melalui pendekatan cara pengolahan pangan yang benar (CPPB) atau Good Manufacturing Practices (GMP) terutama dalam hal tindakan pengendalian kondisi sanitasi dan higi- ene selama pelaksanaan proses produksi tempe.

Secara umum penelitian ini bertujuan untuk mengkaji penerapan prinsip-prinsip mutu dan keamanan pangan dalam memproduksi tempe di Kabupaten Lampung Barat dan secara khusus untuk: 1) menganalisis kondisi sanitasi lingkungan di sekitar pabrik tempe, serta hubungannya dengan bahan baku, kondisi sarana dan prasarana, higiene personel, dan tempe yang dihasilkan; 2) menganalisis bahan baku yang digunakan apakah telah memenuhi syarat mutu dan keamanan pangan, serta hubungannya dengan proses produksi; 3) menganalisis kondisi sarana dan prasarana produksi tempe, apakah sudah memenuhi persyaratan GMP, serta hubungannya dengan proses produksi; 4) menganalisis kondisi higiene personel yang berkaitan langsung dengan produksi tempe dan hubungannya dengan proses produksi; 5) menganalisis proses produksi yang dilakukan pengraj in tempe di Lampung Barat, apakah telah sesuai dengan prinsip mutu dan keamanan pangan dan hubungannya dengan tempe yang dihasilkan; 6) Menentukan titik kritis yang perlu diperhatikan dalam memproduksi tempe di Lampung Barat. 


\section{METODE PENELITIAN}

\section{Desain, Tempat, dan Waktu Penelitian}

Penelitian ini menggunakan desain cross sectional study. Pengambilan data dilakukan di lokasi pabrik tempe yaitu di Kecamatan Sumber Jaya sebanyak 3 pengrajin, Way Tenong sebanyak 1 pengrajin, Balik Bukit sebanyak 7 pengrajin dan Pesisir Tengah sebanyak 4 pengrajin. Kegiatan penelitian dilakukan pada bulan September 2008.

\section{Jenis dan Cara Pengumpulan Data}

Data yang dikumpulkan dalam penelitian ini terdiri dari data primer dan data sekunder. Data primer diperoleh dari hasil pengamatan langsung dan wawancara kepada pengrajin pada lokasi penelitian tentang proses produksi yang dilakukan mereka di setiap tahapan dengan menggunakan panduan kuesioner yaitu meliputi kondisi sanitasi lingkungan di sekitar pabrik, mutu dan keamanan bahan baku, kondisi sarana dan prasarana produksi, kondisi higiene karyawan (personel), dan proses produksinya.

Data skunder terdiri dari data ketersediaan protein dan data jumlah pengraj in yang dihimpun satuan kerja di lingkungan Pemda Kabupaten Lampung Barat, sedangkan data uji organoleptik yang terdiri dari tekstur, warna, bau dan ada tidaknya benda asing dari tempe yang dihasilkan dilakukan oleh 3 (tiga) orang panelis ahli dengan kriteria suka dan sering membeli tempe sehingga mengetahui karakteristik organoleptik tempe yang baik atau buruk dan atau lulusan perguruan tinggi yang memiliki basis pengetahuan pangan.

\section{Pengolahan dan Analisis Data}

Pengolahan data dilakukan dengan menggunakan program komputer Excell dan SPSS. Terhadap jawaban atau kondisi yang positif (ya/ada/baik/ dilakukan/ bersih) diberikan skor atau nilai 1(satu) sedangkan jawaban atau kondisi yang negatif (tidak/tidak ada/tidak baik/tidak dilakukan/tidak bersih) diberi skor atau nilai 0 (nol). Data yang didapat dikelompokan menurut skala usaha berdasarkan kebutuhan kedelai setiap minggu, yaitu kecil $(<400$ $\mathrm{kg})$, menengah $(400-700 \mathrm{~kg})$, dan besar $(>700$ $\mathrm{kg}$ ), serta dilakukan klasifikasi pengendalian yaitu dengan cara memberikan bobot buruk jika capaian pengendaliannya $\varangle 60 \%$ cukup baik jika capaian pengendaliannya $60-75 \%$ dan baik jika capaian pengendaliannya $>75 \%$ di setiap skala usaha. Analisis dilakukan dengan melihat hasil perhitungan rata-rata dan simpangan ba- kunya untuk melihat sebaran/distribusi dari masing-masing penerapan di setiap skala usaha, serta menggunakan pearson untuk melihat korelasinya. Uji mutu organoleptik dilakukan oleh 3 orang panelis ahli terhadap sampel tempe yang langsung diambil dari pabrik yang meliputi terkstur, warna, bau, serta ada tidaknya kotoran dan benda asing.

\section{HASIL DAN PEMBAHASAN}

\section{Penerapan Mutu dan Keamanan Pangan Tempe}

Penerapan prinsip mutu dan keamanan pangan dapat diimplementasikan dalam bentuk penerapan Good Manufacturing Practices (GMP) dan penerapan prinsip lainnya Hazard Analysis Critical Control Point (HACCP). Penerapan GMP dapat dilakukan dengan jalan mengimplementasikannya lagi dalam bentuk dokumen SOP. Dokumen SOP sangat diperlukan karyawan untuk memproduksi pangan dengan cara yang baik, yang dalam hal ini berdasarkan hasil penelitian di lapangan dokumen SOP tersebut belum ditemui.

Hasil penelitian menunjukan bahwa tempe yang dihasilkan para pengrajin di Kabupaten Lampung Barat berdasarkan uji organoleptik bau maupun warna telah sesuai dengan SNI tempe Nomor 01-3144-1998 (Tabel 1). Hal ini menunjukan bahwa walaupun kondisi sanitasi lingkungan dan kondisi sanitasi sarana dan prasarana kurang baik, tetapi mutu dan keamanannya terjamin, karena dapat diatasi pada tindakan pengendalian proses produksi.

Tabel 1. Perbandingan Mutu dan Keamanan Pangan Tempe dengan SNI Tempe berdasarkan Uji Organoleptik

\begin{tabular}{llll}
\hline No & Indikator & \multicolumn{1}{c}{ Hasil Penelitian } & Standar SNI \\
\hline 1 & Bau & Normal khas tempe & Normal khas \\
2 & Warna & $\begin{array}{l}\text { Normal (putih dan } \\
\text { bersih) }\end{array}$ & $\begin{array}{l}\text { Tempe } \\
\text { Normal }\end{array}$ \\
\hline
\end{tabular}

\section{Kondisi Sanitasi Lingkungan di Sekitar Pabrik}

Hasil penelitian menunjukan bahwa pada umumnya pengendalian sanitasi lingkungan di sekitar pabrik setiap skala usaha masih buruk dengan rata-rata capaian $28.57 \%$ (Tabel 2). Sanitasi lingkungan pada skala usaha menengah sedikit lebih baik dengan capaian pengendalian rata-rata sebesar $33.33 \%$ sedangkan pada skala usaha kecil maupun besar yaitu $28.57 \%$ Faktor yang menyebabkannya lebih 
baik adalah lebih terawatnya sarana pengolahan dan tersedianya saluran pembuangan air.

Tabel 2. Kondisi Sanitasi Lingkungan di Setiap Skala Usaha

\begin{tabular}{|c|c|c|c|c|c|c|c|c|}
\hline \multirow{3}{*}{$\begin{array}{l}\text { Sanitasi } \\
\text { Lingkungan }\end{array}$} & \multicolumn{8}{|c|}{ Skala Usaha } \\
\hline & \multicolumn{2}{|c|}{ Kecil } & \multicolumn{2}{|c|}{ Menengah } & \multicolumn{2}{|c|}{ Besar } & \multicolumn{2}{|c|}{ Total } \\
\hline & $\mathbf{n}$ & $\%$ & $n$ & $\%$ & $\mathbf{n}$ & $\%$ & $\mathbf{n}$ & $\%$ \\
\hline Buruk & 8 & 100.0 & 3 & 100.0 & 4 & 100.0 & 15 & 100.0 \\
\hline Cukup baik & 0 & 0.0 & 0 & 0.0 & 0 & 0.0 & 0 & 0.0 \\
\hline Baik & 0 & 0.0 & 0 & 0.0 & 0 & 0.0 & 0 & 0.0 \\
\hline Total & 8 & 100.0 & 3 & 100.0 & 4 & 100.0 & 15 & 100.0 \\
\hline $\begin{array}{l}\text { Nilai rata- } \\
\text { rata } \\
\text { sanitasi } \\
\text { lingkungan } \\
(x \pm \text { SD) }\end{array}$ & \multicolumn{2}{|c|}{$\begin{array}{c}28.57 \pm \\
13.23\end{array}$} & \multicolumn{2}{|c|}{$\begin{array}{c}33.33 \pm \\
16.50\end{array}$} & \multicolumn{2}{|c|}{$\begin{array}{l}25.00 \pm \\
3.68\end{array}$} & \multicolumn{2}{|c|}{$\begin{array}{l}28.57 \pm \\
13.23\end{array}$} \\
\hline
\end{tabular}

Hasil penelitian juga menunjukan bahwa kondisi sanitasi lingkungan berhubungan nyata dengan kondisi higiene karyawan, bahan baku, serta kondisi sarana dan prasarana produksi, tetapi tidak berhubungan langsung dengan mutu dan keamanan tempe yang dihasilkan. Peningkatan kondisi sanitasi lingkungan di sekitar pabrik dapat dilakukan dengan menyediakan tempat sampah tertutup, tempat pembuangan limbah padat, cair dan gas, toilet karyawan, ruang khusus karyawan dan pencegahan binatang. Kebersihan lingkungan yang terjaga dengan baik akan mengurangi potensi-potensi bahaya berupa tempat persembunyian dan perkembangbiakan serangga, binatang-binatang kecil, lalat, tikus, nyamuk dan burung, tempat berkumpulnya debu dan kotoran, gulma, dan lain-lain (Syarief et al., 1999), sedangkan ketiadaan ruang khusus karyawan untuk menyimpan barang dapat berdampak pada terbawanya beberapa barang seperti pensil, pena, jam tangan, trigonal klip, cincin dan benda kecil lainnya akan terbawa ke dalam makanan pada saat mereka bekerja sebagaimana yang disebutkan. Benda-benda kecil dan perhiasan seperti pena, pensil, penjepit kertas, cincin, kalung, jam tangan, dan anting harus ditinggalkan/ dilepas sebelum memasuki daerah pengolahan (J enie, 2000).

Hasil penelitian menunjukan bahwa pada umumnya pengendalian bahan baku di setiap skala usaha cukup baik, dengan rata-rata capaian $69.63 \%$ (Tabel 3). Pengendalian bahan baku pada skala usaha kecil sedikit lebih baik dengan capaian pengendalian rata-rata sebesar $73.61 \%$ sedangkan pada skala menengah $70.37 \%$ dan besar $61.11 \%$ Faktor yang menyebabkannya lebih baik adalah sedikit lebih terkendalinya bahan baku kedelai serta asal sum- ber air dan pengamanannya. Bahan baku harus dibersihkan dan dicuci terlebih dahulu untuk menghilangkan tanah dan mengurangi jumlah mikroba pada bahan mentah. Penghilangan tanah dianggap amat penting karena tanah mengandung berbagai jenis mikroba khususnya dalam bentuk spora (Winarno \& Surono, 2004). Mutu tempe sangat tergantung dari mutu kedelai yang digunakan, kebersihan dan umur simpan, melakukan sortasi, pemilahan serta pembersihan terhadap benda asing (Syarief et al., 1999). Penggunaan kemasan telah dilakukan dengan baik di setiap skala usaha. Peran utama pengemasan dalam pengawetan makanan adalah memberikan perlindungan terhadap masuknya bahan dari luar selama penanganan (Kantor Menteri Negara Urusan Pangan dan PSKPG LP-IPB, 1998).

Tabel 3. Pengendalian Bahan Baku di Setiap Skala Usaha

\begin{tabular}{|c|c|c|c|c|c|c|c|c|}
\hline \multirow{3}{*}{ Kategori } & \multicolumn{8}{|c|}{ Skala Usaha } \\
\hline & \multicolumn{2}{|c|}{ Kecil } & \multicolumn{2}{|c|}{ Menengah } & \multicolumn{2}{|c|}{ Besar } & \multicolumn{2}{|c|}{ Total } \\
\hline & $n$ & $\%$ & $n$ & $\%$ & $n$ & $\%$ & $n$ & $\%$ \\
\hline Buruk & 3 & 37.5 & 1 & 33.3 & 2 & 50.0 & 6 & 40.0 \\
\hline Cukup baik & 0 & 0.0 & 0 & 0.0 & 1 & 25.0 & 1 & 6.7 \\
\hline Baik & 5 & 62.5 & 2 & 66.7 & 1 & 25.0 & 8 & 53.3 \\
\hline Total & 8 & 100.0 & 3 & 100.0 & 4 & 100.0 & 15 & 100.0 \\
\hline $\begin{array}{l}\text { Nilai rata- } \\
\text { rata } \\
\text { kondisi } \\
\text { bahan baku } \\
(x \pm S D)\end{array}$ & \multicolumn{2}{|c|}{$\begin{array}{c}73.61 \pm \\
15.64\end{array}$} & \multicolumn{2}{|c|}{$\begin{array}{c}70.37 \pm \\
12.83^{ \pm}\end{array}$} & \multicolumn{2}{|c|}{$\underset{4.35}{61.11} \pm$} & \multicolumn{2}{|c|}{$\begin{array}{c}69.63 \pm \\
14.83\end{array}$} \\
\hline
\end{tabular}

Hasil penelitian juga menunjukan bahwa pengendalian bahan baku berhubungan dengan kondisi sanitasi lingkungan serta kondisi sarana dan prasarana produksi, tetapi tidak berhubungan langsung dengan tempe yang dihasilkan. Peningkatan mutu dan keamanan bahan baku dapat dilakukan dengan cara menggunakan bahan baku kedelai yang telah bersih sebelum digunakan, menggunakan air dari sumber yang aman, serta dilakukannya tindakan pengamanan dan perlakuan terhadap air yang akan digunakan.

\section{Kondisi Sarana dan Prasasarana Produksi}

Hasil penelitian menunjukan bahwa pengendalian kondisi sarana dan prasarana produksi masih buruk dengan rata-rata capaian $57.00 \%$ (Tabel 4). Pengendalian kondisi sarana dan prasarana skala usaha kecil cukup baik dengan capaian rata-rata $61.25 \%$ dan lebih baik dari pada skala usaha menengah maupun besar. Capaian pengendalian kondisi sarana dan prasarana produksi skala usaha menengah masih buruk yaitu rata-rata $55.00 \%$ tetapi 
lebih baik dari skala usaha besar yang pengendaliannya baru mencapai rata-rata $50.00 \%$ Faktor yang menyebabkan kondisi sarana dan prasarana produksi pada skala usaha kecil lebih baik dari skala usaha menengah maupun besar adalah kondisi keseluruhan bangunan dan perawatannya sedikit lebih baik, kondisi sanitasi diruang pengolahan terutama langitlangit dan lantai sedikit lebih baik, serta penyediaan sarana toilet. Belum baiknya kondisi sarana dan prasarana tersebut merupakan sumber kontaminasi yang perlu diperhatikan (Syarief et al., 1999), sedangkan menurut BPOM (2002) bahwa peralatan pengolahan pangan khususnya yang langsung kontak dengan pangan dapat mencemari pangan jika kotor.

Hasil penelitian juga menunjukan bahwa kondisi sarana dan prasarana produksi berhubungan dengan kondisi sanitasi lingkungan, higiene karyawan, dan bahan baku, tetapi tidak berhubungan langsung dengan tempe yang dihasilkan.

Faktor yang menyebabkan kondisi sarana dan prasarana produksi pada skala usaha kecil lebih baik dari skala usaha menengah maupun besar adalah kondisi keseluruhan bangunan dan perawatannya sedikit lebih baik, kondisi sanitasi diruang pengolahan terutama langitlangit dan lantai sedikit lebih baik, serta penyediaan sarana toilet. Peningkatan pengendalian kondisi sarana dan prasarana produksi dapat dilakukan dengan meningkatkan perawatan dan kebersihan bangunan, penyediaan kotak
PPPK, serta penyediaan sarana pengolahan limbah dan tempat sampah tertutup.

\section{Higiene Karyawan}

Hasil penelitian menunjukan bahwa pada umumnya pengendalian kondisi higiene di setiap skala usaha cukup baik dengan rata-rata capaian $60.95 \%$ (Tabel 5). Faktor yang menyebabkan baiknya higiene karyawan adalah kebiasaan mencuci tangan, tidak menggunakan perhiasan/merokok/makan, dan tidak memberikan mempekerjakan terhadap karyawan yang sedang sakit, sedangkan penyebab kurang baiknya higiene karyawan adalah kurangnya pelatihan/pembinaan, ketiadaan pakaian kerja, dan penggunaan tutup kepala.

Pengendalian kondisi higiene skala usaha besar sedikit lebih baik dari pada skala usaha kecil maupun menengah, yaitu rata-rata mencapai $64.295 \%$ Faktor yang menyebabkan higiene karyawan di skala usaha menengah lebih baik adalah adanya karyawan yang menggunakan penutup kepala saat pelaksanaan produksi. Karyawan disarankan menggunakan topi/tutup kepala, dan hal-hal yang perlu diperhatikan untuk meningkatkan kebersihan (hygiene) karyawan yaitu pendidikan dan pelatihan secara teratur bagi seluruh karyawan, pemeriksaan kesehatan karyawan, kebersihan lingkungan kerja, dan pengawasan yang ketat mengenai praktek sanitasi yang benar (Winarno \& Suroso, 2004).

Tabel 4. Kondisi Sarana dan Prasarana Produksi di Setiap Skala Usaha

\begin{tabular}{|c|c|c|c|c|c|c|c|c|}
\hline \multirow{3}{*}{$\begin{array}{c}\text { Kategori kondisi sarana } \\
\text { dan prasarana }\end{array}$} & \multicolumn{8}{|c|}{ Skala Usaha } \\
\hline & \multicolumn{2}{|c|}{ Kecil } & \multicolumn{2}{|c|}{ Menengah } & \multicolumn{2}{|c|}{ Besar } & \multicolumn{2}{|c|}{ Total } \\
\hline & $\mathbf{n}$ & $\%$ & $\mathbf{n}$ & $\%$ & $\mathrm{n}$ & $\%$ & $\mathbf{n}$ & $\%$ \\
\hline Buruk & 4 & 50.0 & 2 & 66.7 & 2 & 50.0 & 8 & 53.3 \\
\hline Cukup baik & 2 & 25.0 & 1 & 33.3 & 2 & 50.0 & 5 & 33.3 \\
\hline Baik & 2 & 25.0 & 0 & 0.0 & 0 & 0.0 & 2 & 13.3 \\
\hline Total & 8 & 100.0 & 3 & 100.0 & 4 & 100.0 & 15 & 100.0 \\
\hline $\begin{array}{l}\text { Nilai rata-rata kondisi } \\
\text { sarana dan prasarana }(x+S D)\end{array}$ & \multicolumn{2}{|c|}{$61.25 \pm 9.23$} & \multicolumn{2}{|c|}{$55.00 \pm 20.00$} & \multicolumn{2}{|c|}{$50.00 \pm 14.72$} & \multicolumn{2}{|c|}{$57.00 \pm 17.71$} \\
\hline
\end{tabular}

Tabel 5. Kondisi Higiene Karyawan di Setiap Skala Usaha

\begin{tabular}{|c|c|c|c|c|c|c|c|c|}
\hline \multirow{3}{*}{$\begin{array}{c}\text { Kategori kondisi sarana } \\
\text { dan prasarana }\end{array}$} & \multicolumn{8}{|c|}{ Skala Usaha } \\
\hline & \multicolumn{2}{|c|}{ Kecil } & \multicolumn{2}{|c|}{ Menengah } & \multicolumn{2}{|c|}{ Besar } & \multicolumn{2}{|c|}{ Total } \\
\hline & $\mathbf{n}$ & $\%$ & $\mathrm{n}$ & $\%$ & $\mathrm{n}$ & $\%$ & $\mathbf{n}$ & $\%$ \\
\hline Buruk & 5 & 62.5 & 3 & 100.0 & 2 & 50.0 & 10 & 66.7 \\
\hline Cukup baik & 3 & 37.5 & 0 & 0.0 & 2 & 50.0 & 5 & 33.3 \\
\hline Baik & 0 & 0.0 & 0 & 0.0 & 0 & 0.0 & 0 & 0.0 \\
\hline Total & 8 & 100.0 & 3 & 100.0 & 4 & 100.0 & 15 & 100.0 \\
\hline $\begin{array}{l}\text { Nilai rata-rata kondisi } \\
\text { higiene karyawan }(x \pm S D)\end{array}$ & \multicolumn{2}{|c|}{$60.71 \pm 10.10$} & \multicolumn{2}{|c|}{$57.14 \pm 0.00$} & \multicolumn{2}{|c|}{$64.29 \pm 8.25$} & \multicolumn{2}{|c|}{$60.95 \pm 8.48$} \\
\hline
\end{tabular}


Hasil penelitian juga menunjukan bahwa higiene karyawan berhubungan nyata dengan kondisi sanitasi lingkungan serta sarana dan prasarana produksi. Telah cukup baiknya kondisi higiene karyawan ini sesuai dengan BPOM (2002) bahwa terkendalinya higiene karyawan yang bekerja langsung dengan bahan pangan atau pangan dapat mencegah tercemarnya bahan pangan atau pangan dan produk jadi dari: 1) Cemaran fisik berupa masuknya perhiasan, cincin, pena, stappler ke dalam pangan; dan 2) Biologis melalui tangan, kuku, rambut, mulut, hidung dan bagian lainnya, serta cemaran dari karyawan yang sedang mengidap penyakit menular dan yang baru sembuh dari penyakit menular.

\section{Proses Produksi}

Hasil penelitian menunjukan bahwa pada umumnya pengendalian proses produksi di setiap skala usaha telah dilakukan dengan baik yaitu rata-rata mencapai $88.00 \%$ (Tabel 6). Faktor yang menyebabkan baiknya proses produksi adalah terkendalinya pelaksanaan perebusan, pengasaman, pemberian ragi, pembungkusan, pemeraman dan pendistribusian, sedangkan faktor yang memperburuk proses produksi adalah belum bersihnya pelaksanaan pemisahan kulit dari biji kedelai dan saat pencucian. Pengendalian proses produksi pada skala usaha kecil sedikit lebih baik dengan capaian pengendalian rata-rata $88.75 \%$ sedangkan pada skala menengah $86.67 \%$ dan skala besar $87.50 \%$ Faktor yang menyebabkan pengendalian proses produksi di skala usaha kecil sedikit lebih baik adalah pemberian ragi yang telah sesuai ukuran. Kondisi telah dilaksanakan tahapan proses tersebut dengan baik berdampak pada keberhasilan mereka dalam memproduksi tempe sekaligus menjaga mutu dan keamanan tempe. Peningkatan proses produksi dapat dilakukan dengan cara meningkatkan pengendalian terhadap proses pencucian sehingga dihasilkan kedelai yang benar-benar besih.

Syarief et al. (1999) menyebutkan ada beberapa tahapan yang harus dilakukan dalam memproses tempe yang baik, yaitu: 1) perebusan dilakukan di dalam air mendidih sekitar $100^{\circ} \mathrm{C}$ selama 30 menit yang dimaksudkan untuk melunakkan kulit, mengurangi waktu pemasakan serta mengurangi jumlah bakteri yang ada di permukaan kulit; 2) perendaman dilakukan pada saat air rebusan masih panas sampai dingin yang dilakukan selama 8-12 jam karena akan tercapai pH 3.5-5 yang akan menghambat pertumbuhan bakteri pencemar sekaligus mencegah terjadinya kegagalan proses pemeraman, pembentukan flavor daya cerna dan nilai nutrisi dan keawetan tempe yang dihasilkan; 3) pengupasan kulit dilakukan untuk memudahkan pemisahan kulit dari biji kedelai yang dilakukan dengan memeras atau menggunakan alat mekanis; 4) pengasaman dilakukan untuk mencegah hilangnya protein selama pemasakan; dan 5) pemasakan dimaksudkan untuk mengempukan biji kedelai sehingga memudahkan bagi kapang tempe untuk tumbuh.

Tabel 6. Pengendalian Proses Produksi di Setiap Skala Usaha

\begin{tabular}{|c|c|c|c|c|c|c|c|c|}
\hline \multirow{3}{*}{ Kategori } & \multicolumn{8}{|c|}{ Skala Usaha } \\
\hline & \multicolumn{2}{|c|}{ Kecil } & \multicolumn{2}{|c|}{ Menengah } & \multicolumn{2}{|c|}{ Besar } & \multicolumn{2}{|c|}{ Total } \\
\hline & $n$ & $\%$ & $\mathbf{n}$ & $\%$ & $\mathbf{n}$ & $\%$ & $\mathbf{n}$ & $\%$ \\
\hline Buruk & 0 & 0.0 & 0 & 0.0 & 0 & 0.0 & 0 & 0.0 \\
\hline Cukup baik & 0 & 0.0 & 0 & 0.0 & 0 & 0.0 & 0 & 0.0 \\
\hline Baik & 8 & 100.0 & 3 & 100.0 & 4 & 100.0 & 15 & 100.0 \\
\hline Total & 8 & 100.0 & 3 & 100.0 & 4 & 100.0 & 15 & 100.0 \\
\hline $\begin{array}{l}\text { Nilai rata- } \\
\text { rata } \\
\text { pengendalian } \\
\text { proses } \\
\text { produksi } \\
(x \pm S D)\end{array}$ & \multicolumn{2}{|c|}{$\begin{array}{c}88.75 \pm \\
6.41\end{array}$} & \multicolumn{2}{|c|}{$\begin{array}{c}86.67 \pm \\
5.77\end{array}$} & \multicolumn{2}{|c|}{$\begin{array}{c}87.50 \pm \\
5.00\end{array}$} & \multicolumn{2}{|c|}{$\begin{array}{c}88.00 \pm \\
5.61\end{array}$} \\
\hline
\end{tabular}

\section{Titik Kritis yang Perlu Diperhatikan dalam Memproduksi Tempe}

Titik kritis yang perlu diwaspadai dalam memproduksi tempe di Kabupaten Lampung Barat, yaitu: 1) penggunaan air dari sumber air yang bersih dan aman karena akan menimbulkan dampak kemungkinan terjadinya cemaran mikroorganisme, logam dan bahan kimia berbahaya yang dapat menimbulkan risiko bagi kesehatan manusia yang mengonsumsinya; 2) pencucian kedelai sebelum dan sesudah perebusan akan berdampak pada masih terdapatnya kotoran dan benda asing, yang selanjutnya mempengaruhi mutu dan keamanan tempe yang dihasilkan; 3) pengendalian binatang pengerat dan binatang kecil lainnya yang berdampak pada kerusakan bahan baku, peralatan, dan produk jadi, masuknya kotoran, dan sebagai media cemaran mikroba.

\section{Sumbangan dari Ketersediaan Protein Tempe}

Hasil penelitian menunjukan bahwa dari 131 pengrajin tempe yang ada di Kabupaten Lampung Barat selama Tahun 2008 telah memproduksi tempe sebanyak 1510.63 ton. J umlah tempe yang dihasilkan tersebut memberikan kontribusi ketersediaan protein sebesar 1.17 gram/kapita/hari bagi penduduk Kabupaten Lampung Barat. 


\section{KESIMPULAN}

Pada umumnya pengendalian kondisi sanitasi lingkungan belum dilakukan dengan baik oleh para pengraj in tempe di Kabupaten Lampung Barat. Faktor yang memperburuk kondisi sanitasi lingkungan di sekitar pabrik adalah ketiadaan tempat sampah tertutup, tempat pembuangan limbah, dan pencegahan binatang.

Faktor yang menyebabkan buruknya mutu dan keamanan bahan baku adalah belum dibersihkannya kedelai yang akan digunakan dan sumber air yang digunakan. Belum bersihnya mutu bahan baku kedelai tersebut berdampak pada terbawanya kotoran seperti tangkai kedelai, kedelai rusak/cacat, dan terbawanya bij i jagung.

Pengendalian kondisi sarana dan prasarana produksi masih buruk. Faktor yang menyebabkan buruknya pengendalian kondisi sarana dan prasarana produksi adalah belum dilakukannya perawatan dan kebersihan bangunan, ketiadaan kotak PPPK, serta ketiadaan tempat sampah tertutup dan sarana pengolahan limbah.

Pada umumnya higiene karyawan sudah cukup baik yang ditunjukan dengan adanya kebiasaan mencuci tangan, tidak menggunakan perhiasan, tidak merokok, tidak makan, dan tidak mempekerjakan karyawan yang sedang sakit. Sedangkan penyebab kurang baiknya higiene karyawan adalah kurangnya pelatihan/ pembinaan, ketiadaan pakaian kerja, dan penggunaan tutup kepala.

Proses produksi yang dilakukan pengrajin tempe secara umum sudah baik. Baiknya proses produksi didukung oleh terkendalinya pelaksanaan perebusan, pengasaman, pemberian ragi, pembungkusan, pemeraman dan pendistribusian. Sedangkan faktor yang memperburuk proses produksi adalah belum bersih- nya pelaksanaan pemisahan kulit dari biji kedelai dan saat pencucian.

Terdapat tiga titik kritis yang perlu diperhatikan dalam memproduksi tempe di Kabupaten Lampung Barat yaitu: 1) penggunaan air dari sumber air yang bersih dan aman; 2) pencucian kedelai sebelum dan sesudah perebusan sampai bersih; dan 3) pengendalian binatang pengerat dan binatang kecil lainnya.

\section{DAFTAR PUSTAKA}

[BPOM] Badan Pengawas Obat dan Makanan. 2002. Panduan Pengolahan Pangan Yang Baik Bagi IRT, J akarta.

[BSN] Badan Standar Nasional. 1999. SNI 013144-1998, tentang Tempe Kedelai, J akarta.

Jenie BSL. 2000. Sanitasi dan Higiene Pengolahan Pangan: Analisis Bahaya dan Pencegahan Keracunan Pangan, J akarta.

Kantor Menteri Negara Urusan Pangan. 1996. Undang-Undang Republik Indonesia Nomor 7 Tahun 1996, tentang Pangan. Kantor Menpangan, J akarta.

Syarief $R$, Hermanto J, Hariyadi $P$, Wiraatmadja S, Suliantari, Dahrulsyah, Suryatna NE, Saragih PY, Hendrasari J, Arisasmita, Kusumawardani I, \& Astuti M. 1999. Wacana Tempe Indonesia. Universitas Katolik Widya Mandala Press, Surabaya.

Winarno FG. \& Surono. 2004. GMP, Cara Pengolahan Pangan yang Baik. Mbrio Press, Bogor. 